\title{
FTSE, WHO Code and the Infant Formula Industry
}

\author{
Stewart Forsyth \\ University of Dundee, Dundee, UK
}

In 1981, the Thirty-Fourth World Health Alliance adopted the fourth draft of the International Code of Marketing of Breast Milk Substitutes (BMS), with the expectation that the Code would contribute to the safe and adequate provision of nutrition for infants, and in particular protect and promote breastfeeding $[1,2]$. It was also anticipated that the Code would provide the framework for effective cooperation between key stakeholders; however, this has not been fulfilled and the self-governing arrangements set out in the Code have failed to prevent 3 decades of acrimonious exchanges and boycotts, predominantly between non-governmental organizations and industry [3]. In the meantime, non-compliance with the Code continues to be reported [4]. It has been proposed that there is an urgent requirement for the establishment of independent international governance structures that are transparent, sustainable and effective [5].

An unexpected but interesting governance initiative has now emerged. The initiative is led by the FTSE Group, which is an independent company jointly owned by the Financial Times and London Stock Exchange Group and is a world leader in the development of indices used by investors to assess business portfolios, performance and risks [6]. It is most widely known for its indices relating to financial markets. In 2001, FTSE launched
FTSE4Good, which was designed to act as a tool for investors who are interested in companies with acknowledged records of corporate social responsibility including environmental sustainability, human rights and stakeholder involvement [7].

Following discussions with UNICEF, FTSE4Good has now established an index for companies that operate in the BMS sector with the expectation that these companies will secure their inclusion in the FTSE4Good investment index by demonstrating that they meet specific marketing standards $[8,9]$. The FTSE4Good BMS Marketing Committee has collaborated with an independent provider of research into company governance and ethical performance (EIRIS), and developed BMS marketing criteria that not only build on the WHO Code and subsequent World Health Alliance resolutions but also address the need for effective internal company management systems. This process included consultation with companies, investors and non-governmental organizations, including both UNICEF UK and Save the Children.

If a BMS manufacturer meets the criteria to be included in the index, the company will then have an independent verification assessment to determine if their practices on the ground follow their policies [10]. This will

\section{KARGER \\ Fax +4161306 1234 \\ E-Mail karger@karger.ch}

www.karger.com (c) 2012 S. Karger AG, Basel

0250-6807/12/0602-0154\$38.00/0

Accessible online at:

www.karger.com/anm
Prof. Stewart Forsyth

University of Dundee

1 Ellieslea Road, West Ferry

Dundee DD5 1JG (UK)

Tel. +44 1382778 465, E-Mail stewartforsyth@btinternet.com 
become an annual requirement and the assessment includes providing evidence of senior executive responsibility, training of sales and marketing staff, internal monitoring, compliance mechanisms, whistle-blowing procedures and response to allegations. PricewaterhouseCoopers $(\mathrm{PwC})$ has been appointed as the assessor for the first cycle of assessments.

Initial assessments will be undertaken in 2 'higherrisk' countries on the understanding that the risk of negative consequences from inappropriate marketing of BMS will be greatest in these countries. The criteria defining a higher-risk country include rates of child malnutrition and child mortality, and using these criteria 149 countries have now been identified at 'higher risk' by FTSE. FTSE will subsequently focus on activities in lower-risk countries. The infant formula and food companies currently involved in the assessment phase include Abbott Laboratories, Danone, Heinz, Meiji Dairies, Pfizer and Nestlé.

In March 2011, Nestlé became the first company to meet the FTSE4Good selection criteria, and the company then had a verification assessment of its practices in India and Zambia between April and August 2011. In a report from the Chief Executive of the FTSE Group to Nestlé on November 14, 2011, it was stated that 'on balance' Nestlé was meeting the criteria and had therefore maintained its position in the index [11]. However, there were aspects of policy and practice that Nestlé needs to address and these will be reviewed during further verification assessments in 2012.

The reactions of stakeholders and observers to this new initiative are likely to reflect a mix of encouragement, caution and possibly suspicion. However, FTSE, EIRIS and $\mathrm{PwC}$ have global reputations for the assessment of performance, ethics and audit within business and their expertise will undoubtedly enhance the scrutiny of policies and practices in the infant formula industry. FTSE emphasizes that the initiative is an evolutionary process, with the key components being engagement, gaining trust and continuous improvement.

The credibility of the initiative will largely depend upon the robustness of the verification assessment. Correspondence from the FTSE Chief Executive to IBFAN (International Baby Food Action Network) clearly indicates that the verification is against the FTSE4Good criteria and not against the WHO Code per se [12]. He indicates that the assessors will not be acting as judge on specific allegations but will be restricting their audit to assessing whether practices on the ground are in line with company policy. For assurance on the rigour of the assessment, the verification tool and the final report of all verification assessments will need to be made available in the public domain.

With 149 countries now identified to be at high risk, the selection of only 2 countries to determine whether a company is meeting the set criteria may raise doubts on the comprehensiveness and validity of the assessment. A larger representation at the initial verification assessment with fewer countries involved as spot checks at subsequent assessments may provide greater assurance on the overall performance of the company. The countries are currently selected by a risk assessment matrix devised by the auditors PwC and the BMS Expert Committee.

With the effectiveness of the Code having hitherto been undermined by long-standing self-regulatory failure, the FTSE initiative should be viewed as an opportunity to strengthen the Code with governance structures that are robust and independent. The initiative, however, is still at an early stage of development and for it to be sustainable it will not only require a substantive and transparent commissioning process but also commitment from key stakeholders across the infant feeding community. This should be achieved by embracing the original spirit of the Code, which is that participation and cooperation are essential if activities aimed at improving infant nutrition are to be successful [2].

\section{References}

1 World Health Assembly: Resolutions of the Executive Board at its Sixty-Seventh Session and of the Thirty-Fourth World Health Assembly on the International Code of Marketing of Breast Milk Substitutes. Resolution EB67.R12; in World Health Organization: International Code of Marketing of Breast Milk Substitutes. Geneva, WHO, 1981.
2 World Health Organization: International Code of Marketing of Breast Milk Substitutes. Geneva, WHO, 1981.

3 Baby Milk Action. http://www.babymilkaction.org/ (accessed January 2012).

4 Koletzko B: Marketing of dietetic products for infants and young children in Europe three decades after adoption of the International Code of Marketing of Breast Milk Substitutes. Ann Nutr Metab 2011;59:7072.

\footnotetext{
5 Forsyth JS: International Code of Marketing of Breast-Milk Substitutes - three decades later time for hostilities to be replaced by effective national and international governance. Arch Dis Child 2010;95:769-770.

6 FTSE The Index Company: Adding values to your investment. FTSE4Good Index Series 5 year review. http://www.ftse.com/Indices/ FTSE4Good_Index_Series/Downloads/ F4G_5Year_Review.pdf (accessed January 2012).
} 
7 FTSE The Index Company: FTSE Group leads collaboration to improve breast milk substitute marketing practices (media information). http://www.ftse.com/Media_Centre/Press_Releases/2011/20110210_FTSE_ Group_leads_collaboration_to_improve_ Breast_Milk_Substitute_marketing_practices.doc (accessed January 2012).

8 FTSE4Good: A note on the new FTSE4Good breast milk substitute (BMS) marketing criteria and its impact on the FTSE4Good March 2011 Review. http://www.ftse.com/ Indices/FTSE4Good_Index_Series/Downloads/FTSE4Good_Web_Update_March_ 2011.pdf (accessed January 2012).
9 FTSE4Good Inclusion criteria for the marketing of breast milk substitutes. http:// www.ftse.com/Indices/FTSE4Good_Index_Series/Downloads/F4G_BMS_Criteria.pdf (accessed January 2012).

10 FTSE The Index Company: FTSE4Good breast milk substitutes (BMS) marketing criteria and its application. http://www.ftse. com/Indices/FTSE4Good_Index_Series/ FTSE_BMS_Criteria.jsp (accessed January 2012).
11 Letter from the Chief Executive, FTSE Group to Chief Executive Officer, Nestle S.A. 14th November 2011. http://www.ftse.com/Indices/FTSE4Good_Index_Series/Downloads/ FTSE_Letter_to_Nestle.pdf (accessed January 2012).

12 Letter to Regional Coordinator, IBFAN, Asia. 17th June 2011. http://www.ftse.com/ Indices/FTSE4Good_Index_Series/Downloads/Letter_to_IBFAN.pdf (accessed January 2012). 